\title{
Difficulties in Learning Early Literacy in Primary Schools
}

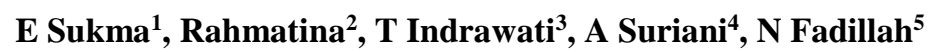 \\ \{elfiasukma@fip.unp.ac.id ${ }^{1}$ \} \\ 1,2,3,4,5 Universitas Negeri Padang, Prof. Dr. Hamka Street, Air Tawar, Padang, Indonesia
}

\begin{abstract}
Literacy is very important for students because the skills in literacy affect the success of their learning and life. In early writing literacy, students are expected to be able to produce writing that can begin with spelling writing. This study aims to determine the problems faced by teachers in early reading literacy. This research uses a qualitative approach. The research subjects were in grade 1 and 2 elementary school teachers. The results showed that the reading difficulties faced by students appearing to be improper reading habits, mistakes in knowing words, mistakes in understanding reading. In reading students have difficulty in distinguishing letters, such as distinguishing the letters $\mathrm{p}$ and $\mathrm{d}$, $\mathrm{m}$ and $\mathrm{n}$, and $\mathrm{b}$ and $\mathrm{d}$. As a result, students have difficulty in producing writing, both orally and in writing.
\end{abstract}

Keywords: Learning early literacy, primary School

\section{INTRODUCTION}

Early reading literacy aims to make students have the ability to understand and voice writing with reasonable intonation, as a basis for further reading. The purpose of beginning reading is also explained in so that students can read simple words and sentences smoothly and precisely [1]. Furthermore, the initial writing aims so that students can write simple words and sentences correctly. In early writing literacy, students are expected to be able to produce writing that can begin with spelling writing. Examples of writing $\mathrm{m}, \mathrm{n}, \mathrm{b}$, and $\mathrm{d}$ can be syllables such as ma-na, bu-di, and in simple sentence form. Besides, so students understand how to write the beginning with the correct spelling, then the letter by letter is introduced gradually until finally all the letters are mastered by students.

Based on that objective literacy skills in reading and writing are basic skills in language for early grade students. Students need to achieve success in the future. However, in reality, the reading ability of elementary students is still worrying as can be seen based on the following data. First, based on the results of a survey by the Organization for Economic Cooperation Development (OECD), it shows that the reading culture of Indonesian people occupies the lowest position of 52 countries in East Asia [2]. Second, based on PISA (Program for International Student Assessment) data, in 2015, Indonesia ranked 64 out of 70 countries evaluated. Third, based on PIRLS (Program in International Reading Literacy Study) data in 2011, Indonesia ranked 45th out of 48 countries evaluated. Fourth, based on a survey from UNESCO Indonesia ranked second lowest in interest in reading. Fifth, based on reports from 
the IEA Study of Reading Literacy, the ability of elementary school children in Indonesia is still very low, whereof the 31 countries studied, Indonesia ranks 30th.

Reading skills are activities that are needed by anyone who wants to advance and improve themselves. Reading skills are one of the keys to students' success in achieving success. Efforts to develop and improve reading skills in primary schools must be able to equip students with the basic reading skills needed to continue at a higher level of education. This means that to improve reading skills, students must master initial reading skills. Because beginning reading is the foundation to be able to master advanced reading skills. Beginning reading is the initial reading given to children in grades I and II as a basis for further learning [3]. The reading ability obtained at the beginning of reading is very influential on the ability to read further [4]. As an ability that underlies the next ability, the ability to read the beginning requires the attention of the teacher, because if the base is not strong, at the advanced reading stage the child will have difficulty being able to have adequate reading skills [5]. Reading comprehension is closely related to all academic achievements. Therefore, this should be the teacher's attention to introduce the activity of beginning reading in a way that introduces early literacy to students [6].

Early literacy is not interpreted as an activity to teach reading but makes students love reading activities and builds a foundation for reading so that later when students have time to learn to read they are more prepared [7]. Student literacy experience is believed to form a strong foundation on the development of reading [8]. Students' knowledge, skills, and attitudes that form the basis of reading and writing are called early literacy abilities [9].

The problem of low literacy reading in early elementary school students as expressed by students still stammered when reading a series of sentences. Uneasy reading like this is because children focus too much on the decoding process. Furthermore, who researched in the second grade of the elementary school stated that the reading difficulties faced by students appeared in four forms, namely unfamiliar reading habits, mistakes in knowing words, errors in understanding reading, and symptoms of various kinds [10]. The low reading ability was also expressed by the problem of mastering reading and writing skills made students weak and uninterested in Malay language subjects. Reading problems that exist in students such as mistakenly distinguish uppercase and lowercase letters when reading, do not pronounce words correctly, can not mention the word that is spelled and often leave words that do not know their meaning. Besides, students are also weak and are not interested in finding the information contained in pictures or stimulation materials provided by the teacher. Unlike the research that has been done, this research will discuss problems that are not only experienced by students but also experienced by teachers in teaching reading in early elementary school classes. By doing so, this study aims to recognize the problems of reading literacy in early elementary school classes and how the teacher teaches it.

\section{Method}

In this study, researchers used qualitative methods to find problems in early reading learning in elementary schools through interviews with teachers. The interview technique used is half structured. The subject or respondents of this study were elementary school teachers in the city of Padang. Researchers need to get information about problems in reading literacy in elementary classes.

Therefore, the selection of qualitative research respondents uses the snowball technique. The technique of taking respondents with snowballs refers to the research respondents so that 
the respondents appoint other respondents to be interviewed [11]. The respondents indicated to be interviewed are the best respondents to provide comprehensive information.

For this purpose, the researcher has interviewed a teacher in North Padang (hereinafter referred to as Respondent 1 or abbreviated R1). This R1 gives information about the respondents that will be met next, namely from the area of South Padang (R2) as a representative of South Padang. Then the researcher requested information from R2 to prepare respondents to be interviewed in the West Padang and Nanggalo regions (R3 and R4) representing the western region. After interviewing respondents from the western region, the researchers asked respondents for the eastern region, namely the Kuranji and East Padang regions (R5 and R6). This process is repeated so that the researcher gets the correct data until there is saturation of the data. Retrieval of data using structured interviews between researchers and respondents interviewed. Respondents were interviewed based on the questions provided and additional questions were asked based on answers from respondents and following the information needs of the researcher. In this research, the data analysis technique used is thematic analysis.

In this research, the data analysis technique used is thematic analysis. This thematic analysis model contains three stages, namely data reduction, data display, and data verification (verifying) [12].

\section{Results and Discussion}

\subsection{Result}

The following is described the results of the research obtained based on the results of interviews with 6 respondents, there are R1, R2, R3, R4, R5, and R6. From the cognitive domain, the problems experienced by teachers are the lack of understanding of teachers to the nature of reading and writing, the lack of understanding of teachers in teaching reading and writing. In the affective aspect the lack of motivation of teachers in reading and writing. As for the psychomotor aspect is the learning process of reading and writing has not been implemented optimally, and the assessment process has not been done optimally.

\section{Lack of Master's Understanding of the Nature of Reading}

The nature of reading refers to the understanding, purpose, and benefits of reading. Studies can show that teachers are less able to teach language skills because teachers understand the notion of reading skills as expressed by R3 respondents. Respondents R2 stated that teachers still lack understanding of reading skill because some elementary school teachers have non graduate background from PGSD department. This affects the learning of reading. Furthermore, the problem experienced by teachers in reading skills is in understanding the purpose and benefits in learning reading skills as expressed by respondents R3.

\section{Lack of Master's Understanding of the Nature of Writing}

The essence of writing refers to the understanding, purpose, and benefits of reading. Studies show that teachers are less able to teach language skills because teachers understand the notion of writing skills as expressed by the R3 respondent. Respondent R2 stated that teachers still do not understand the essence of writing skill because some elementary school teachers have non graduate background from PGSD department. This affects the learning of writing. Furthermore, the problem experienced by teachers in writing skills is in understanding the purpose and benefits in learning writing skills as expressed by respondents R 1 . 


\section{Lack of Master's Understanding of Linguistic Learning}

In presenting learning material of writing language which need to be mastered is model of learning. The goal is that the learning objectives can be achieved optimally. The difficulties experienced by most teachers are not yet understanding the appropriate learning model that can be used in learning the language of writing, choosing the appropriate learning with the level of student development and the steps of using the learning model. As expressed by respondents R1 that teachers who lack the mastery of learning will result in students being not interested in the learning provided by the teacher. Based on statements expressed by respondents $\mathrm{R} 1$ revealed that if the teacher is difficult to determine the appropriate learning, consequently the learning is not interesting for students and students difficult to understand the material presented by the teacher. Thus the less than optimal subject objectives are achieved optimally as expressed by respondents $\mathrm{R} 1$.

\section{Lack of Teacher Motivation in Reading}

Motivation needs to be possessed by a teacher. With the motivation, a teacher can create various learning experiences for students. Studies can show that teachers' motivation in reading less. This is in accordance with that revealed by respondents R2 that the lack of motivation to students in the subjects of language. If a teacher has a lack of motivation in teaching reading learning, of course this will result in students also less motivated in learning.

\section{Lack of Teacher Motivation in Writing}

Motivation needs to be possessed by a teacher. With the motivation, a teacher can create various learning experiences for students. Studies can show that teachers' motivation in writing less. This is in accordance with that revealed by respondents R2 that the lack of motivation to students in the subjects of language. If a teacher has a lack of motivation in teaching writing lessons, this will certainly lead to students also less motivated in learning.

\section{Reading Learning has not been implemented optimally}

Studies can show that teachers are having problems teaching reading skills. The problem is the ability of teachers to teach reading skills, the use of media in learning, the use of learning methods, subjects are still besifat cognitive, and the selection of learning materials. The ability of teachers in teaching reading skills is how teachers present reading subjects so that learning is meaningful for students. As stated by respondent R2. Indonesian language subjects, especially reading skills in elementary schools can not be separated from the ability of teachers in designing learning, such as the selection of materials and learning models. As revealed by respondents R2 that teachers are less able to choose materials and learning models in accordance with the development and ability of students so that the effect on students' reading ability. In addition, the problem experienced by teachers is the use of media in learning. As stated by respondents R3 that the use of appropriate learning media can support the implementation of learning including reading skills.

\section{Learning Writing has not been implemented optimally}

Studies can show that teachers have problems teaching their writing skills. The problem is the ability of teachers to teach writing skills, the use of media in learning, the use of learning methods, subjects are still besifat cognitive, and the selection of learning materials. 
The ability of teachers in teaching writing skills is how teachers present writing subjects so that learning is meaningful for students. As stated by respondent R2. Indonesian language subjects, especially writing skills in elementary schools can not be separated from the ability of teachers in designing learning, such as the selection of materials and learning models. As revealed by respondents $\mathrm{R} 2$ that teachers are less able to choose materials and learning models in accordance with the development and ability of students so that the effect on students' reading ability. In addition, the problem experienced by teachers is the use of media in learning. As stated by respondents R3 that the use of appropriate learning media can support the implementation of learning including writing skills.

\section{The assessment process has not been done optimally}

The purpose of the assessment is to measure skills in different contexts. Based on the results of the study found that some teachers still experience difficulty in assessing the learning activities of written language, as expressed by respondents R3 Assessment needs to be done by the teacher. Assessment is done to see student progress in learning writing language. For that teachers need to know the aspects that need to be assessed in the subjects of writing language such as assessing the ability meyimak and tell stories as expressed by R2. Understand the language assessment procedure Write (R1). Furthermore, the difficulties experienced by teachers are in understanding the assessment procedure. The point is when the judgment is done as in the beginning, the process, and the end. As expressed by respondents R2 that teachers difficulties in understanding the procedures of writing language assessment. Though writing language assessment procedures needed to measure the success of learning.

\subsection{Discussion}

That in many studies it was found that teachers have a significant influence in mastering reading habits and developing reading skills [13]. The reading interest of Indonesian citizens is very low. The survey results stated that the Indonesian people watched more television, listened to the radio, played games rather than read books and ranked 124 out of 187 countries in the world rating index [14].

The results of the study showed that in general, literacy of literary masters in the aspect of knowledge is still very low, especially literary which is classified as classical, while the ability to express an impression of reading the opposite. In conclusion, to measure literacy is not right if knowledge is the only literary measurement tool.

Literacy in the aspect of knowledge is still very low, especially literature which is classified as a classic, while the ability to express the impression of reading the opposite. In conclusion, to measure literacy is not right if knowledge is the only literary measurement tool. Media is a tool used as a messenger from the sender to the recipient of the message. That media is everything that carries information between the source of information and the recipient [10].

\section{Conclusion}

The results showed that the reading difficulties faced by students appearing to be improper reading habits, mistakes in knowing words, mistakes in understanding reading. In reading students have difficulty in distinguishing letters, such as distinguishing the letters $\mathrm{p}$ and $\mathrm{d}, \mathrm{m}$ and $\mathrm{n}$, and $\mathrm{b}$ and $\mathrm{d}$. As a result, students have difficulty in producing writing, both orally and in writing. 


\section{Acknowledgments}

Thank you to Universitas Negeri Padang for permitting this research.

\section{References}

[1] DesJardin J L, Ambrose S E, and Eisenberg L E 2008 Literacy skills in children with cochlear implants: The importance of early oral language and joint storybook reading, Journal of Deaf Studies and Deaf Education, 14 (1) 22-43

[2] Hapsari W, Ruhaena L, and Pratisti W D 2017 Improvement of early literacy ability of preschoolers through the stimulation program Jurnal Psikologi, 44 (3), 177-184

[3] Handayani F N 2019 Implementation of the school literacy movement through reading angles in children aged 5-6 years in Zhafira Kindergarten, Keboansikep GedanganSidoarjo UIN Sunan Ampel Surabaya

[4] Lee V E and Croninger R G 1994 The relative importance of home and school in the development of literacy skills for middle-grade students American Journal of Education, 102 (3) 286-329

[5] Mustikawati D A 2016 Code transfer and code mixing between seller and buyer (analysis of language learning through sociolinguistic s tudies) Jurnal Dimensi Pendidikan dan Pembelajaran, 2 (2) 23-32

[6] Cromley J G, Snyder-Hogan L E, and Luciw-Dubas U A 2010 Reading comprehension of scientific text: A domain-specific test of the direct and inferential mediation model of reading comprehension, Journal of Educational Psychology, 102 (3) 687

[7] Brown D M et al 2010 Ranibizumab for macular edema following central retinal vein occlusion: six-month primary end point results of a phase III study, Ophthalmology, 117 (6) $1124-1133$

[8] Ruhaena L, Karyani U, and Iswinarti I 2014 Development of a multisensory model for early stimulation of preschoolers' basic read writing capabilities, Universitas Muhammadiyah Surakarta

[9] Whitehurst G J and Lonigan C J 2001 Emergent literacy: Development from prereaders to readers Handbook of Early Literacy Research, 1 11-29

[10] Dunst, C J, Simkus A, and Hamby D W 2012 Children's story retelling as a literacy and language enhancement strategy, Center for Early Literacy Learning 5 (2) 1-14

[11] Ritchie J, Lewis Nicholls C M, and Ormston R 2013 Qualitative research practice: A Guide for Social Science Students and Researchers

[12] Miles M B, Huberman A M 1994 Qualitative Data Analysis: An Expanded Sourcebook. Sage Pub.

[13] Timbang T, Mahamod Z, and Hamat A 2016 Factors and impressions of reading problems among royal low school students in Brunei Darussalam Jurnal Pendidikan Bahasa Melayu, 1 (1) 89-107

[14] Rizkiana R 2016 Difficult analysis of reading the beginning of class I students in Bangunrejo 2 Primary School Yogyakarta Basic Education, 5 (34) 3-236-3.251 